\title{
Correction to: P_RNA_scaffolder: a fast and accurate genome scaffolder using paired- end RNAsequencing reads
}

Bai-Han Zhu' ${ }^{1,2+}$, Jun Xiao ${ }^{1,2+}$, Wei Xue ${ }^{1}$, Gui-Cai Xu ${ }^{1,3}$, Ming-Yuan Sun ${ }^{1,2}$ and Jiong-Tang Li ${ }^{1 *}$

\section{Correction to: BMC Genomics (2018) 19:175}

https://doi.org/10.1186/s12864-018-4567-3

Following the publication of this article [1], the authors reported that the link to the software described in the article is no longer valid. They have therefore provided the following alternative address in this Correction article in order to gain access to the software: https://github.com/ CAFS-bioinformatics/P_RNA_scaffolder

\footnotetext{
Author details

'Key Laboratory of Aquatic Genomics, Ministry of Agriculture, CAFS Key Laboratory of Aquatic Genomics and Beijing Key Laboratory of Fishery Biotechnology, Chinese Academy of Fishery Sciences, Beijing 100141, China. ${ }^{2}$ College of Fisheries and Life Science, Shanghai Ocean University, Shanghai 201306, China. ${ }^{3}$ College of Marine Science, Zhejiang Ocean University, Zhoushan 316022, China.
}

Received: 29 May 2019 Accepted: 29 May 2019

Published online: 26 June 2019

\section{Reference}

1. Zhu, et al. P_RNA_scaffolder: a fast and accurate genome scaffolder using paired-end RNAsequencing reads. BMC Genomics. 2018;19:175 https://doi. org/10.1186/s12864-018-4567-3

\footnotetext{
* Correspondence: lijt@cafs.ac.cn

${ }^{\dagger}$ Bai-Han Zhu and Jun Xiao contributed equally to this work.

${ }^{1}$ Key Laboratory of Aquatic Genomics, Ministry of Agriculture, CAFS Key Laboratory of Aquatic Genomics and Beijing Key Laboratory of Fishery Biotechnology, Chinese Academy of Fishery Sciences, Beijing 100141, China Full list of author information is available at the end of the article
}

(c) The Author(s). 2019 Open Access This article is distributed under the terms of the Creative Commons Attribution 4.0 International License (http://creativecommons.org/licenses/by/4.0/), which permits unrestricted use, distribution, and reproduction in any medium, provided you give appropriate credit to the original author(s) and the source, provide a link to the Creative Commons license, and indicate if changes were made. The Creative Commons Public Domain Dedication waiver (http://creativecommons.org/publicdomain/zero/1.0/) applies to the data made available in this article, unless otherwise stated. 